\title{
Factors of the Use of E-learning during COVID-19 Lockdown among the College Students of Nepal: A Cross-Sectional Study
}

\author{
Poonam Pokhrel Sapkota \\ Program Incharge, Public Health Faculty, Balkumari College \\ pmsnancy@gmail.com \\ Dr. Shyam Prasad Sedai \\ Program Incharge, Education faculty, Balkumari College \\ shyamsedhai@hotmail.com \\ Megha Raj Sapkota \\ Senior Medical Laboratory Technologist, B.P.K.M.C.H. \\ pmsnancy@gmail.com
}

\begin{abstract}
Background: COVID-19 Pandemic had affected all sectors of human life around the globe. Education is one of them where traditional method of teaching had to be shift to virtual learning all of sudden in both developed and developing countries. Therefore, the article reflects the associated factors of E-learning among college students of Nepal during emergency shift of teaching paradigm due to COVID -19.
\end{abstract}

Methodology: Convenient sampling method through social media and Google form was used to collect 385 data from college students of Nepal during COVID-19 lockdown.

Results: The result showed that only $30 \%$ of the Nepalese students had all the required resources all the time for the use of E-learning however, $85 \%$ of the student had engaged in in E-learning during COVID-19 pandemic lockdown. The study found that gender, marital status, training on the use of E-learning, experience of E-learning prior to pandemic were statistically significant with the future use of E-learning.

Conclusions: Educational institutions need be responsive towards the challenges faced by students during E learning, so that learning needs of the students will be fulfilled even in pandemic situation. Keywords: E-learning, Higher education, College students, COVID-19, Crisis education

Keywords: Orwell, imagery as a literary device, allegory, symbol, life-like, violence.

Corona Virus Disease (COVID-19) has grown to be the only topic of discussion in 2020 around the world since it was first reported in Wuhan, China on $31^{\text {st }}$ December 2019 (World Health Organization, 2020). WHO declared Public Health Emergency of International Concern on 30

January, 2020. As of 08 July 2020, there were 11.95 million global infected cases resulting 546,700 deaths around the Globe whereas, Nepal has 16,168 confirmed positive cases with 35 death starting from January 23, 2020(WHO, 2020).

Most of the countries had restricted Domestic and International travel, shutdown of all places of large gatherings including academic institutions schools, college, offices, stores and other public places to respond as the preventive measures of the novel Corona Virus disease (C, OwusuFordjoue, C.K., Koomson, D., 2020). Government officials and public health experts are engaging in several measures, including social distancing, self-isolation, quarantine, strengthening health facilities, asking people to work from home to control the epidemic inside the country (Mustafa, 2020).

A UNESCO report has shown that 150 countries have closed schools and educational institutions, impacting over 80\% of the world's student population since March 25, 2020 (Wan, 2020). A typical number of universities, colleges and schools across the world have either postponed or cancelled all events such as exams, conferences, workshops, sports (inside or outside the institution)(Sahu, 2020). Various courses in Universities have switched from face-toface to online education delivery mode. Similarly, Nepal has also adopted most of the measures as 
of other countries including announcement of school and colleges shut down since $19^{\text {th }}$ March 2020 which affect primary level students to University level students. School students were ready to sit on their final exam and most the graduate college students are in mid of the session and post graduate students are near to start their new session("Nepal to Introduce 'Digital

Education' Amid COVID-19 Lockdown," 2020.). Therefore, many schools, colleges and universities had started to resume their sessions through E-learning portals. A study conducted in Western region of Nepal in 2018 shown that $50 \%$ of the students prefer E-learning over classroom settings however, the prerequisite of the virtual class has to be provided (Sharma \& Bhatta, 2018). This study carried out the determining factors of the use of E-learning during COVID-19 lockdown among the college students of Nepal.

\section{Methodology}

A Cross-sectional with a quantitative approach was used to collect the data from the 385 college students who were pursuing their higher study in colleges of Nepal. Sample size was calculated by $\frac{\boldsymbol{z}^{2} \boldsymbol{p}(\mathbf{1}-\boldsymbol{p})}{\text {. Convenient }}$ Sampling technique was used applying all due ethical concerns. Semistructured questionnaire were prepared in Google-Form and shared to head of the departments of the different college, and then they were distributed to the students through concerned college teacher. Informed verbal consent was taken with the respondents prior to questionnaire and written letter was given to the manager of the institution. STATA.13.0 was used for data analysis.

\section{Findings and Discussions}

Students were from the age group of 17 to 37 years with the median age of 20 . The sociodemographic characteristics of the study population were presented in the Table 1 . more than one third students $37 \%$ were pursuing their degree from CTEVT affiliated colleges followed by (36\%) Tribhuvan University. Others were from Purvanchal University (11\%), Kathmandu University (8\%), Pokhara University (5\%) and National Academy of Medical Sciences (NAMS) (3\%) (Figure 1).

Table 1: Socio-demographic characteristics

\begin{tabular}{|ll|l|l|}
\hline & Characteristics & Frequency (n) & $\begin{array}{l}\text { Percentage } \\
(\%)\end{array}$ \\
\hline \multirow{2}{*}{ Current age (in years) } & $17-23$ & 323 & 84 \\
& $24-30$ & 47 & 12 \\
Gender & $31-37$ & 15 & 4 \\
& Female & 332 & 86 \\
Marital status & Male & 53 & 14 \\
\hline \multirow{2}{*}{ Family type } & Unmarried & 350 & 91 \\
& Married & 35 & 9 \\
\hline \multirow{2}{*}{ Residence } & Nuclear family & 299 & 78 \\
& Joint family & 86 & 22 \\
\hline & Urban area & 200 & 52 \\
& Semi-urban area & 141 & 36 \\
& Rural area & 44 & 12
\end{tabular}




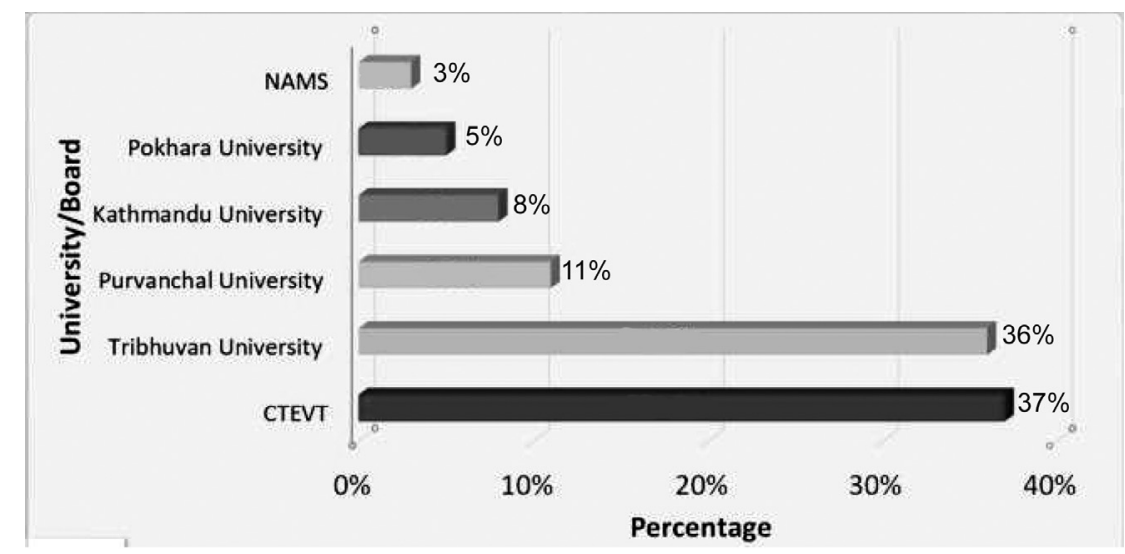

Figure 1: Distribution of the college students according to Universities/Board

More than half of them (53\%) were from Proficiency Certificate Level and 36\% and 11\% were from Bachelor and Master Level respectively. Nearly two third respondents $65 \%$ were studying Nursing whereas others were agriculture (8\%), Public Health and Science 6\% each, Hotel management (4\%), education, management and Humanities 3\% each and rest were pursuing their degree in other faculty. As the COVID-19 lockdown became lengthier, the E-learning became familiar from school to colleges. Nearly, $85 \%$ of students were engaged in E-learning from the college whereas, only $19 \%$ had experience of E-learning prior to the current situation (Figure 2).
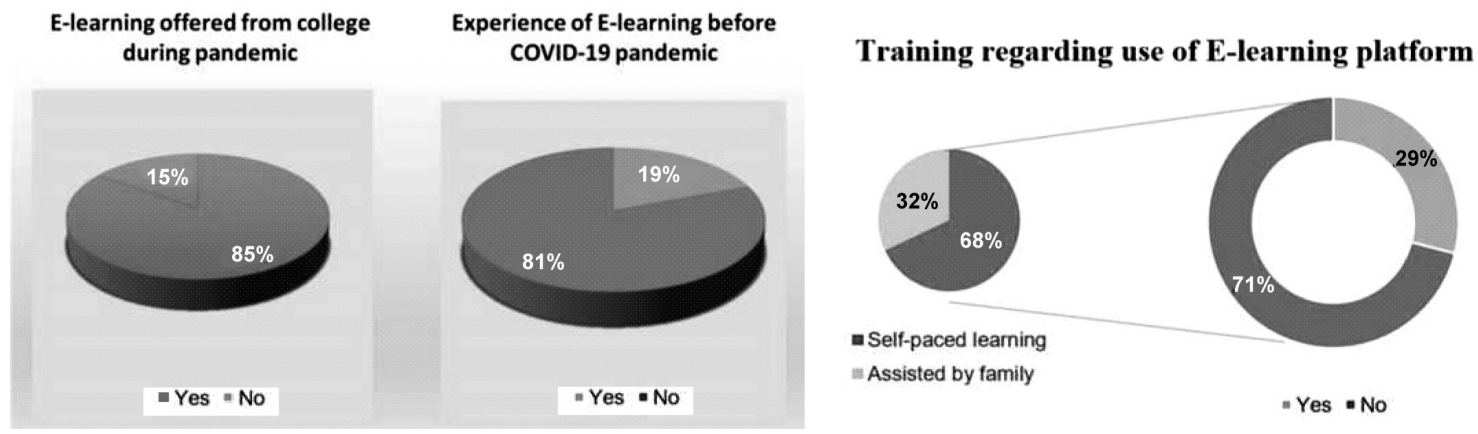

Figure 2: E-learning offered \& prior experience

Figure 3: Training regarding use of E-learning

Further more, only 111 (29\%) of the respondents got training on how to use E-learning from the colleges. Among the respondents who didn't get formal training from their own college use selfpaced learning or assisted by family and friends by $68 \%$ and $32 \%$ respectively (Figure 3 ).

The College students were asked about the essential resources needed, their availability, financial burden, internet facility etc. More than $80 \%$ of the respondents responded that the device for Elearning like smart phone, laptop; internet accessibility, software application were the crucial resources needed for the one to participate in E-learning. Likewise, nearly $80 \%$ of the respondents responded electricity as essential resources followed by separate room $60 \%$. About one third of the respondent has chosen IT skill needed for the use of E-learning (Figure 4).

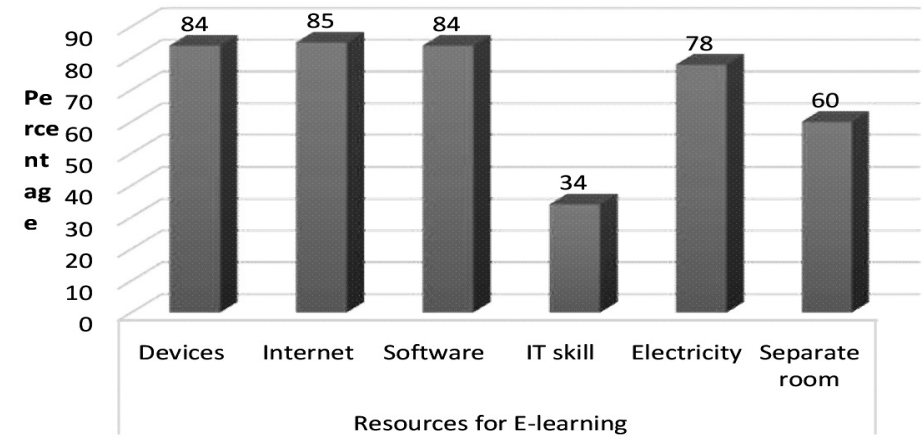

Figure 4: Resources needed for E-learning 
The respondents were asked the status of availability of the resources they had chosen. Only $109(29 \%)$ had the resources all the time whereas more than two third of the respondents $264(69 \%)$ had partial availability and rest $12(3 \%)$ didn't have at all. Meanwhile, $59 \%$ of the respondents shared their device with family members which may affect their learning. They had used various internet service provider such as Worldlink, $36 \%$ followed by ADSL net 12\%, N-cell data, NT Fiber net, Classictech 10\% each. Rests of them were NTC data (6\%), Vianet (5\%), E-pacakage data of NTC or N-Cell (3\%), TechMind (3\%), Subisu (2\%), TPLink (1\%). At last, College students were probed whether they wish for E-learning in future? Only $44 \%$ desire E-learning in future. In bivariate analysis, the study found that the future use of E-learning was statistically significant with Gender, Marital Status, Level of study, their experience of E-learning, training, availability of resources with Pearson Chi-square test $<0.05$. (Table 2)

Table 2 Association of future use of E-learning with other independent variables

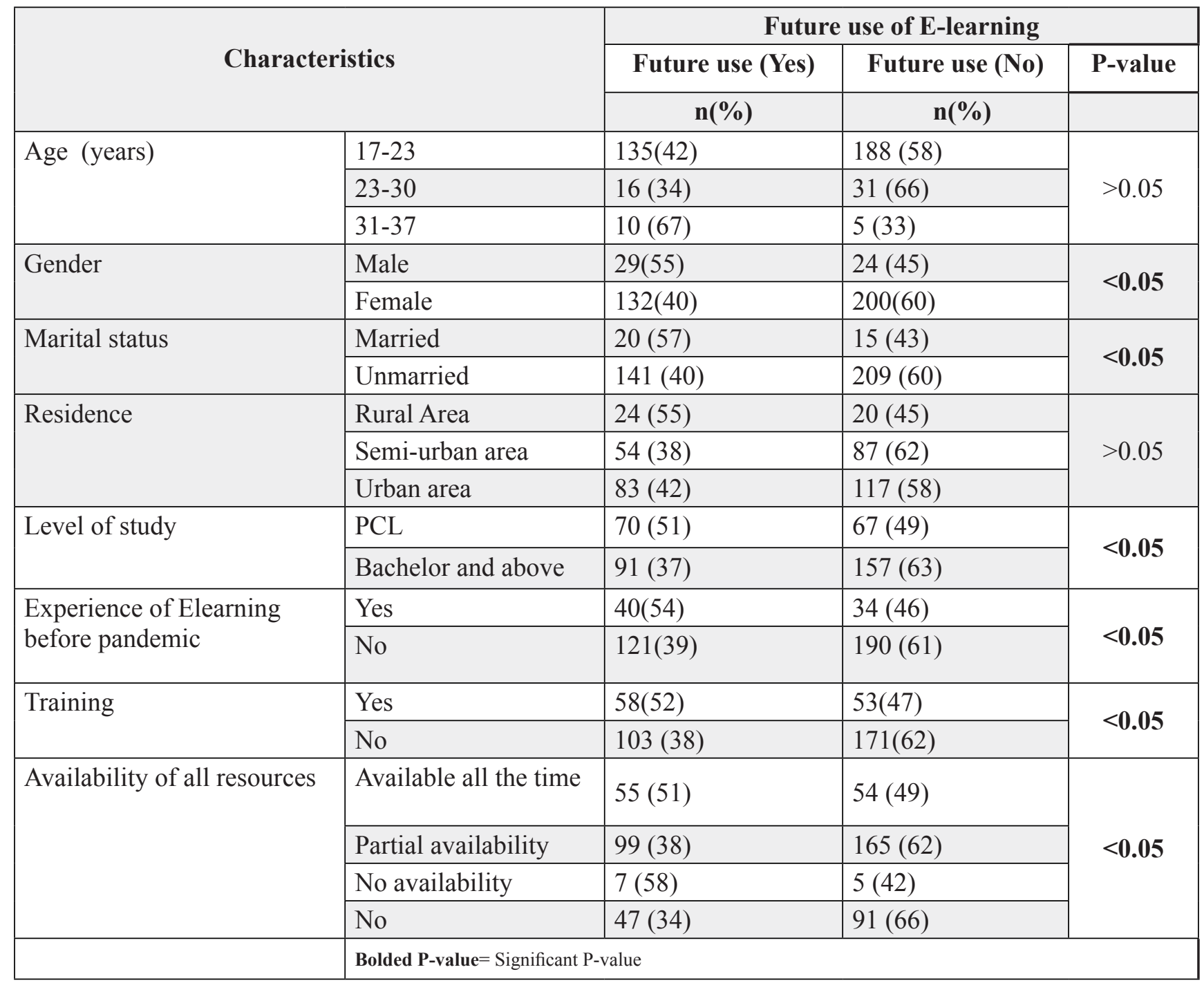

\section{Discussion:}

E-learning became the alternative of crisis response in education during COVID 19 pandemic. There is no certainty of COVID 19 pandemic deceased. Social distancing is the only measure of new normal life from now and onwards. Therefore, educational stakeholders have to be prepared for virtual classes even in post-pandemic arena. This study tried to reflect the associated factors of E-learning which will ultimately impact on future use of E-learning.

More than $80 \%$ of the respondents preferred smart phone as the pre-requisite of the E-learning which was aligned with the study of India (T et al., 2020). The educational organizations may have to develop application that will be compatible for smart phones for the virtual mode of education. 
Inadequate availability of the resources like internet facility, IT skills will demotivate the learners to participate in the online platform. In contrast, availability of necessary resources was statistically significant with the future use of E-learning among the college students. Similar findings were shown in India, Pakistan and Nepal (T et al., 2020, Samikshya, 2020, Kanwal \& Rehman, 2017).

\section{Conclusion:}

In conclusion, COVID-19 pandemic gave a great lesson and showed the exact scenario of crisis preparedness in education sector. Higher education policy makers have to rethink the teaching methods in different innovative ways in future, which will enable the college students to adopt the emergency management in education sector. Education system has to be strengthened with cooperation and collaboration among the policymakers, communities and other concerned stakeholders of national and International. College students and teacher both have to be trained enough in various ways of teaching learning method as well as college capacity has to be strengthened in terms of IT sector in future.

\section{Implication of the study:}

There is no certainty about the length of the COVID-19 pandemic and remerging of the infections, social distancing became the motto of new normal life. All the educational institutions need to prepared and modify their course structure to shift majority of the course content to Elearning. Educational stakeholders had to promote higher education institutions with infrastructural facilities that can be adjusted to online education/ E-learning. Government should ensure that the education budget for 2020 will be fully implemented and the basic infrastructure for online education like internet facility, trainings on IT skills, online library will be strengthened around the country.

\section{Limitation:}

Convenient Sampling method was applied for data collection due to the COVID-19 Pandemic lockdown situation therefore the researcher couldn't gather equal number of respondents among the faculties.

\section{REFERENCES}

C, Owusu-Fordjoue, C.K., Koomson, D., H. (2020). European Journal of Education Studies THE

IMPACT OF COVID-19 ON LEARNING -. European Journal of Education Studies, 7(3), 88-101. https://doi. org/10.5281/zenodo.3753586

Mustafa, N. (2020). IMPACT OF THE 2019-20 CORONAVIRUS PANDEMIC ON EDUCATION. International Journal of Helath Preferences Research.

Nepal to Introduce 'Digital Education' Amid COVID-19 Lockdown. (n.d.).

Sahu, P. K. (2020). Closure of Universities Due to Coronavirus Disease 2019 ( COVID-19 ): Impact Closure of Universities Due to Coronavirus Disease 2019 ( COVID-19): Impact on Education and Mental Health of Students and Academic Staff. Cureus, 12(4). https://doi.org/10.7759/cureus.7541

Sharma, G., \& Bhatta, M. P. B. (2018). Advances in Computer Sciences. Adv Comput Sci, 1(3), 1-11.

Wan, Y. S. (2020). Education during COVID-19. Brief Ideas, $n^{\circ}$ 19(April), 3-9.

WHO. (2020). WHO Coronavirus Disease (COVID-19) Dashboard. WHO.

World Health Organization. (2020). Coronavirus disease 2019. 